\title{
An empirical investigation on factors influencing intention of use of internet banking
}

\author{
Mohammad Pourasadi ${ }^{\mathrm{a}}$ and Leyla Dastanian ${ }^{\mathrm{b}^{*}}$
}

${ }^{a}$ Police University Amin, Tehran, Iran

${ }^{b}$ Department of Management, Tehran North Branch, Islamic Azad University, Tehran, Iran

\section{H R O N I C L E}

Article history:

Received August 25, 2013

Received in revised format

19 September 2013

Accepted 23 October 2013

Available online

November 112013

Keywords:

Perceived ease of use

Perceived usefulness

Trust

Internet banking

\section{A B S T R A C T}

One of the most important techniques for development of internet banking is to encourage people to do their daily banking transactions through internet facilities. In this paper, we present an empirical study to find out whether perceived ease of use, perceived usefulness as well as trust could influence on internet banking. The proposed study was implemented in one of Iranian banks in city of Tehran, Iran using structural equation modeling. Cronbach alpha has been calculated as 0.90 , which validates the overall questionnaire. Using structural equation modeling, the survey has concluded that perceived ease of use $(\beta=0.18, p$-value $=0.000)$, perceived usefulness $(\beta=0.24$, $p$-value $=0.000)$ and trust $(\beta=0.55, p$-value $=0.000)$ had positive and meaningful impact on internet banking.

\section{Introduction}

During the past few years, there have been growing interests in internet banking in the world (Agarwal et al., 2009; Akturan \& Tezcan, 2012). People use internet banking to pay bills, visit their financial transactions (Moon \& Kim, 2001), transfer funds between different accounts, etc. and most banks' managers wish to understand factors for promoting internet banking (Calisir \& Gumussoy, 2008; Chau, \& Ngai, 2010). Internet banking these days is not something new anymore; all the banks in the Romanian market are offering various forms of Internet banking, which is eventually a service in the cloud. Frăţilă et al. (2013) briefly analysed the Romanian Internet banking market, compared some of the most popular Internet banking platforms and gave some conclusions about this market in the context of the new Cloud computing delivery frameworks.

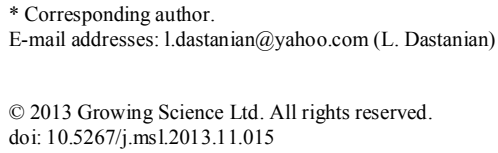


Arfaeian et al. (2013) presented a survey to study the role of personal and social characteristics on acceptance of internet banking adoption in province of Alborz, Iran. They examined the effects of five factors including Neuroticism, Extraversion, Openness to experience, Conscientiousness and Agreeableness on e-banking adoption. Using regression techniques, they confirmed that Neuroticism and Agreeableness had negative and meaningful impact on internet banking adoption while Conscientiousness had positive and meaningful relationship with internet banking adoption.

Lee et al. (2013) performed an empirical investigation of the security of Internet banking and financial private information in South Korea. Subsorn and Limwiriyakul (2012) performed a comparative analysis of Internet banking security in Thailand. The investigation indicated that there was a distinct lack of internet banking security information provided on all the selected Thai banks' websites as compared with the selected Australian banks, which provided better internet banking security information. Reis et al. (2011) discussed how to develop an education system for secure internet banking.

One of the primary concerns on internet banking is the possibility of fraud on the cyberspace where many people prefer not to trust internet banking. In such events, many people prefer to use traditional methods for handling their daily business activities. These problems also keep potential negative consequences such as increase in perceived risk, loss of trust and needs for better security, which may be suboptimal from an economical perspective (van der Meulen, 2013). Ariff et al. (2012) investigated the effects of computer self-Efficacy and technology acceptance model on behavioral intention in Internet banking systems. Normalini and Ramayah (2012) investigated whether biometrics technologies implementation in Internet banking could reduce security issues or not. They explained that the benefits of investigating biometric authentication systems in online banking would secure the $\log$ in process to the system and it could remove password vulnerabilities; enhanced convenience such as employees quickly log in using their finger; reduced help desk expenses by eliminating calls for password resets.

Chavoshi et al. (2013) studied the effects of electronic banking effects on key customer relationship management (CRM) components and concluded that improving customer relationship process was the most important factor followed by providing appropriate service for each customer, providing appropriate service on appropriate time for each customer and providing appropriate service by appropriate channel for each customer. Azad et al. (2013) detected important factors influencing on electronic banking adoption using factor analysis and reported that four major factors including consistency, facilities, cost control and feasibility maintained the most important effect on e-banking.

Esmaeili et al. (2013) investigated different factors influencing customer loyalty in e-banking and reported that "satisfaction" was the most influential component affecting customer loyalty formation and trust formation in customers could also impact loyalty in an electronic environment with a 70\% diagnose coefficient.

\section{The proposed study}

The proposed study of this paper performs an investigation to detect important factors influencing intention of use of internet banking. The sample size of the survey includes all customers of Bank Sepah in city of Tehran, Iran who have automated teller machine (ATM) card and it is calculated as follows,

$$
n=\frac{N \times z_{\alpha / 2}^{2} \times p \times q}{\varepsilon^{2} \times(N-1)+z_{\alpha / 2}^{2} \times p \times q},
$$


where $N$ is the population size, $p=1-q$ represents the yes/no categories, $z_{\alpha / 2}$ is CDF of normal distribution and finally $\varepsilon$ is the error term. Since we have $p=0.5, z_{\alpha / 2}=1.96$ and $N=450$, the number of sample size is calculated as $n=210$. Fig. 1 demonstrates the summary of the proposed model of this paper (Nor et al., 2010).

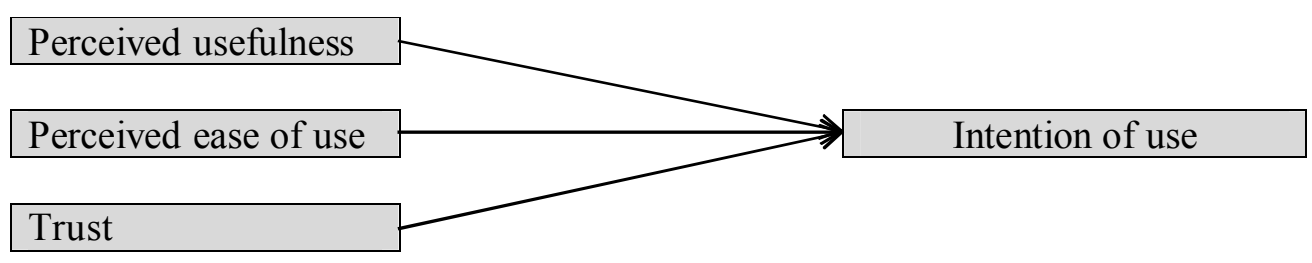

Fig. 1. The proposed study (Nor et al., 2010)

Table 1 demonstrates the results of Cronbach alpha before and after the survey has been accomplished.

Table 1

The summary of Cronbach alpha

\begin{tabular}{lcc}
\hline & \multicolumn{2}{c}{ Cronbach alpha } \\
\cline { 2 - 3 } Variable & Pre-test & Post-test \\
\hline Perceived on ease of use & 0.63 & 0.76 \\
Perceived useflness & 0.84 & 0.84 \\
Trust & 0.83 & 0.86 \\
Intention to use & 0.94 & 0.93 \\
\hline Total & 0.87 & 0.90 \\
\hline
\end{tabular}

The proposed study considers the following three hypotheses,

1. First hypothesis: Perceived on ease of use influences on intention of use of internet banking.

2. Second hypothesis: Perceived usefulness influences on intention of use of internet banking.

3. Third hypothesis: Trust influences on intention of use of internet banking.

The proposed study uses structural equation modelling to verify different hypotheses of the survey.

\section{The results}

\subsection{Structural equation modeling}

In this section, we present details of the implementation of structural equation modelling to verify various hypotheses of the survey. Fig. 2 demonstrates the summary of the results of the proposed model. In Fig. 2, there are three variables including perceived on ease of use (PEU), perceived usefulness (PU) and trust (TR) and the effects of these variables are considered on intention to use (INT). According to the results of Fig. 2, Root Mean Square Error of Approximation (RMSEA) is equal to 0.073 , which is less than desirable limit of 0.09 . In addition, Chi-Square is equal to 149.89 with p-value of 0.0000. In addition, Goodness of Fit Index (GFI), Adjusted Goodness of Fit Index (AGFI) and Normed Fit Index (NFI) are equal to $0.91,0.85$ and 0.95 , respectively. These numbers are also within desirable limits and we can conclude that the results of SEM are reliable. 


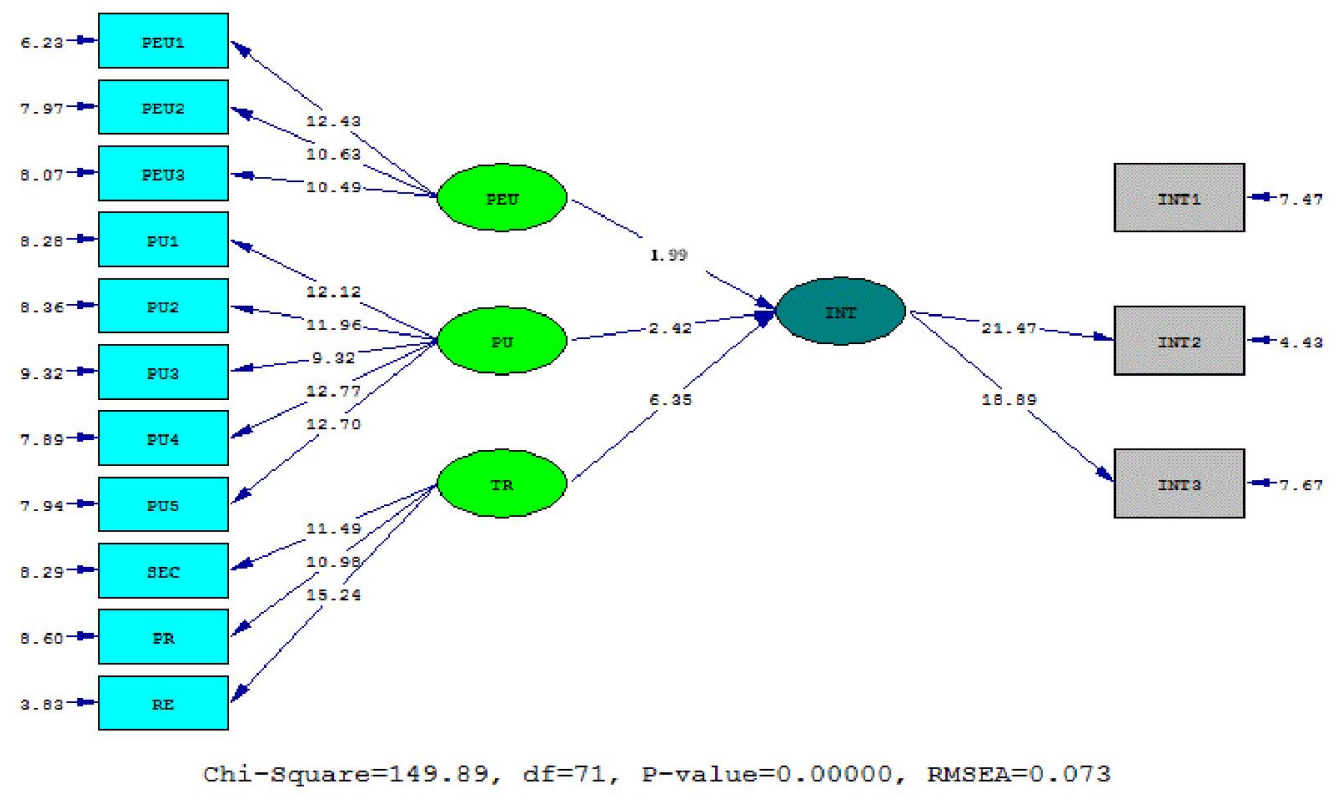

Fig. 2. The results of standard values for structural equation modeling

\subsection{Testing hypotheses}

\subsubsection{The first hypothesis}

The first hypothesis of the survey investigates whether perceived ease of use influences on intention use of internet banking or not.

$\mathrm{H}_{01}$ ) There is not any meaningful relationship between perceived ease of use and intention of use of internet banking $\left(\mathrm{H}_{01}: \mathrm{B}_{\mathrm{i}}=0\right)$.

$\mathrm{H}_{11}$ ) There is a meaningful relationship between perceived ease of use and intention of use of internet banking $\left(\mathrm{H}_{11}: \mathrm{B}_{\mathrm{i}} \neq 0\right)$.

As shown in Fig. 2, the variable coefficient of PEU is 0.18 where t-student is equal to 1.99. According to t-statistic and p-value of this variable, we conclude that the coefficient is significant at the 0.05 level. Therefore, perceived ease of use has positive and meaningful effect on intention use of internet banking and $\mathrm{H}_{1}$ assumption of the first hypothesis is accepted.

\subsubsection{The second hypothesis}

The second hypothesis of the survey investigates whether perception of usefulness has a meaningful effect on e-banking.

$\left.\mathrm{H}_{02}\right)$ Perceived of usefulness does not have any impact on intention use of internet banking $\left(\mathrm{H}_{02}: \mathrm{B}_{\mathrm{i}}=\right.$ $0)$.

$\left.\mathrm{H}_{12}\right)$ Perceived of usefulness has some impact on intention use of internet banking $\left(\mathrm{H}_{12}: \mathrm{B}_{\mathrm{i}} \neq 0\right)$.

As shown in Fig. 2, the variable coefficient of PU is 0.24 where t-student is equal to 2.42. According to t-statistic and p-value of this variable, we conclude that the coefficient is significant at the 0.05 level. Therefore, perceived usefulness has positive and meaningful effect on intention use of internet banking and $\mathrm{H}_{1}$ assumption of the second hypothesis is accepted. 


\subsubsection{The third hypothesis}

The third hypothesis of the survey investigates whether trust could contribute on intention use of internet banking or not.

$\left.\mathrm{H}_{03}\right)$ Trust has no influences on intention use of internet banking $\left(\mathrm{B}_{\mathrm{i}}=0\right)$.

$\left.\mathrm{H}_{13}\right)$ Trust influences on intention use of internet banking $\left(\mathrm{H}_{13}: \mathrm{B}_{\mathrm{i}} \neq 0\right)$.

As shown in Fig. 2, the variable coefficient of TR is 0.55 where $t$-student is equal to 6.35. According to $t$-statistic and $p$-value of this variable, we conclude that the coefficient is significant at the 0.05 level. Therefore, trust has positive and meaningful effect on intention use of internet banking and $\mathrm{H}_{1}$ assumption of the third hypothesis is accepted.

\section{Conclusion}

One of the most important methods for development of internet banking is to encourage people to do their daily banking transaction through internet facilities. In this paper, we have performed an empirical investigation to find out whether perceived ease of use, perceived usefulness as well as trust could influence on internet banking. The proposed study has been implemented in one of Iranian banks in city of Tehran, Iran using structural equation modeling. The survey has concluded that three independent variables, indeed, have had positive and meaningful impact on internet banking.

\section{Acknowledgement}

The authors would like to thank the anonymous referees for constructive comments on earlier version of this paper.

\section{References}

Agarwal, R., Rastogi, S., \& Mehrotra, A. (2009). Customers' perspectives regarding e-banking in an emerging economy. Journal of Retailing and Consumer Services, 16(5), 340-351.

Akturan, U., \& Tezcan, N. (2012). Mobile banking adoption of the youth market: Perceptions and intentions. Marketing Intelligence \& Planning, 30(4), 444-459.

Arfaeian, A., Ghorbanifard, B., Mousavi, S \& Aziziha, H. (2013). Investigating personal characteristics on e-banking adoption. Management Science Letters, 3(12), 2939-2944.

Ariff, M.S.M., Yeow, S.M., Zakuan, N., Jusoh, A., Zaidi Bahari, A. (2012). The effects of computer self-Efficacy and technology acceptance model on behavioral intention in Internet banking systems. Procedia - Social and Behavioral Sciences, 57(9), 448-452

Azad, N., Seyedaliakbar, S., Mousavirad, S \& Mousavirad, S. (2013). An exploration study on factors influencing acceptance of electronic banking industry. Management Science Letters, 3(6), 1783 1788.

Calisir, F., \& Gumussoy, C. A. (2008). Internet banking versus other banking channels: Young consumers' view. International Journal of Information Management, 28(3), 215-221.

Chau, V. S., \& Ngai, L. W. (2010). The youth market for internet banking services: perceptions, attitude and behaviour. Journal of Services Marketing, 24(1), 42-60.

Chavoshi, K., Ramezanzadeh, A., Ahmadvand, S., Amaleh, K \& Rezaei, B. (2013). An empirical investigation on the effects of electronic banking on key customer relationship management. Management Science Letters, 3(12), 3013-3018.

Esmaeili, M., Nazarpoori, A \& Najafi, M. (2013). An investigation on loyalty formation model in ebanking customers: A case study of banking industry. Management Science Letters, 3(3), 903-912. 
Frăţilă, L.A., Zota, R.D., \& Constantinescu, R. (2013). An Analysis of the Romanian Internet Banking Market from the Perspective of Cloud Computing Services. Procedia Economics and Finance, 6, 770-775.

Lee, J.H., Lim, W.G., \& Lim, J.I. (2013). A study of the security of Internet banking and financial private information in South Korea. Mathematical and Computer Modelling, 58(1-2), 117-131

Moon, J. W., \& Kim, Y. G. (2001). Extending the TAM for a World-Wide-Web context. Information \& Management, 38(4), 217-230.

Normalini, M.K., \& Ramayah. T. (2012). Biometrics technologies implementation in Internet banking reduce security issues?. Procedia - Social and Behavioral Sciences, 65(3), 364-369.

Nor, K. M., Sutanonpaiboon, J., \& Mastor, N. H. (2010). Malay, Chinese, and internet banking. Chinese Management Studies, 4(2), 141-153.

van der Meulen, N.S. (2013). You've been warned: Consumer liability in Internet banking fraud. Computer Law \& Security Review, 29(6), 713-718.

Reis, Z.A., Gülseçen, S., \& Bayrakdar, B. (2011). To develop an education system for secure internet banking: GIBES. Procedia Computer Science, 3, 1333-1340

Subsorn, P., \& Limwiriyakul, S. (2012). A comparative analysis of Internet banking security in Thailand: A Customer Perspective. Procedia Engineering, 32, 260-272. 